\title{
Dynamics of hydrocarbon production in long-developed fields of the South Caspian basin with emphasis on reserves renewability
}

\author{
A. A. Feyzullayev ${ }^{1}$ (D) I. Lerche ${ }^{2} \cdot$ I. M. Mamedova ${ }^{3} \cdot$ A. G. Gojayev ${ }^{3}$
}

Received: 13 July 2020 / Accepted: 16 January 2021 / Published online: 8 March 2021

(c) The Author(s) 2021

\begin{abstract}
The scientific basis of the paper is the concept of renewability of oil and gas resources. In accordance with this concept, the purpose of this paper is to estimate the volumetric rate of natural replenishment of the reservoir with oil and gas using the example of long-developed Bibieybat oil and Garadag gas condensate fields in the South Caspian Basin (SCB). The methodological approach of this assessment is based on the authors' assumption that at the late stage of field development, the recoverable amount of hydrocarbon fluids is compensated by the amount of their natural inflow, as a result of which oil or gas production stabilizes. The analysis of the dynamics of hydrocarbon production for the Bibieybat oil field covered the period from 1935 to 2018, and for the Garadag gas condensate field from 1955 to 1979 . The rate of natural oil replenishment calculated for 29 operating facilities of the Bibieybat field varies per well within 0.32-1.4 ton/day (averaging 0.76 ton/day) or about 277 ton/year. The rate of natural gas inflow at the Garadag gas condensate field is about 5.2 thousand $\mathrm{m}^{3} /$ day per well.
\end{abstract}

Keywords Petroleum field development $\cdot$ Petroleum production rate $\cdot$ Reservoir $\cdot$ Natural gas and oil inflow

\section{Introduction}

For more than a century, hydrocarbon (HC) raw materials have been intensively used in our daily lives and continue to be the main source of energy for world civilization. However, since oil is a non-renewable resource and its reserves in the subsurface are limited, the consumer could not help but worry about the time to reach the peak of global oil production and the beginning of decline. In this regard, the world community has been actively discussing the prospects for oil production for many years.

The most well-known attempt to forecast the peak of oil production was made in 1956 by King Hubbert (Hubbert 1956). Studying the dynamics of growth in oil production in the USA, he predicted that the USA would have peak

I. Lerche

lercheian@yahoo.com

1 Institute of Geology and Geophysics of Azerbaijan National Academy of Sciences, H.Cavid av. 119, Baku AZ1143, Azerbaijan

2 Institut Für Geowissenschaften, Naturwissenschaftliche Fakultät III, Martin-Luther-Universität, Halle, Germany

3 State Oil Company of Azerbaijan (SOCAR), Baku, Azerbaijan production between 1965 and 1970, after which production would inevitably decline. His calculations were confirmed in practice-after 1971, US oil production really began to decline. However, an attempt to predict the peak of world oil production was unsuccessful.

According to the US Energy Information Administration (Goloskokov 2010), world crude oil production hit a plateau in 2004 with a 2005 maximum of 73.71 million barrels per day, after which there has been a gradual decline until the recent advent of shale fracking.

The Oil and Gas Peak Research Association (ASPO), founded by British geologist Colin Campbell, using modern information about known oil deposits, estimated future discoveries, growing oil demand and available technology, predicted that global production would peak around 2010 (Campbell 2002).

In a report by the British Council for Energy Research, which advises the UK government on global energy markets, the risk of reaching a critical point, the so-called oil peak, may occur by about 2020 (Oil 2009).

According to the Institute of Petroleum Geology and Geophysics of the Siberian Branch of the Russian Academy of Sciences, the peak of world oil production will fall between 2030 and 2040, when about $4.6-4.8$ billion tons will be produced annually (Kontorovich 2009). 
The International Energy Agency predicts the onset of the “oil peak" by 2030 (Peak of Oil 2010).

Thus, there is currently no consensus on the expected date of the world peak of oil production and the beginning of its decline. Despite modern advances in oil and gas exploration geology, geophysics and geochemistry, the development of their scientific and methodological foundations, an increase in investments in prospecting and exploration, a large-scale increase in oil reserves is not observed (Goloskokov 2010).

The future of oil production is associated with searches on continental shelves (including the Arctic) and in deep water, as well as the development of tar sands and shale oil. Alternative energy sources cannot yet be considered competitive in comparison with traditional resources.

In this situation, Sokolov and Guseva (1993) put forward the idea that oil and gas fields are renewable sources of hydrocarbons. This statement aroused great interest among scientists and specialists in the oil and gas industry of Russia and served as an impetus for intensive research in order to verify the validity of the new oil and gas paradigm. The idea was sharply debated at all major conferences and meetings held in Russia. As a result, based on the example of a number of oil and gas fields being developed in Russia (Northern Caucasus, Western Kuban, Samara and VolgaUral regions, Tatarstan and Western Siberia) (Ashirov et al. 2000; Muslimov et al. 2004; Muslimov 2007; Zakirov et al. 2009; Kayukova et al. 2012; Muslimov, Plotnikova 2018; Kucherov, 2016; Iktisanov, Zakirov 2019), as well as in India and the USA (Zapivalov 2012), to date, many facts have accumulated confirming the existence of a replenishment process.

Plotnikova (2004); Gavrilov (2008); Kasyanova (2010); Khisamov et al. (2012); Trofimov (2013); and Goryunov et al. (2015) all suggest the existence of oil and gas supply centers and channels (fault and weakened zones)that are used to replenish reservoirs. As a rule, high-flow-rate (socalled abnormal) wells are confined to these zones.

After intensive development of readily available oil reserves, the proposal is to replenish oil reserves through rehabilitation cycles (Zapivalov 2012).

This problem is extremely important scientifically and practically and so requires the continuation and expansion of comprehensive studies.

From this point of view, the South Caspian Basin (SCB), which is one of the oldest oil and gas provinces in the world where oil and gas fields have been developed since the beginning of the last century, is an excellent testing ground for such studies.

This paper is based on an analysis of field data for the dynamics of oil and gas production at a number of longterm developed fields in the South Caspian Basin, a detailed study of the possibility of the self-filling process, and if it is possible to give a quantitative assessment of the rate of natural recharge by hydrocarbons.

\section{Background}

The implementation was carried out on two long-term developed fields in the SCB: The Bibieybat oil field and the Garadag gas condensate field. The main development of the SCB is the productive series (PS), Lower Pliocene (Fig. 1).

\section{Bibieybat field}

The Bibieybat petroleum field, one of the first fields in Azerbaijan, is located in the southwestern coastal part of the Absheron Peninsula, $2 \mathrm{~km}$ south of Baku.

Since ancient times, oil production has taken place. In 1846 , the first well in the world was drilled here, from which industrial oil inflows from PS were obtained. From then until the present day this area is an industrial oil development field.

The Bibieybat field is a brachyanticline fold of northwestern strike with a gentle $\left(25-30^{\circ}\right)$ northeast and relatively steeper southwest wings. A buried mud volcano is located at the crest of fold (Fig. 2).

The thickness of the PS within this area reaches $1700-1800 \mathrm{~m}$ and is an ordinary terrigenous lithofacies, but with a slightly increased clay content. Within the Bibieybat field industrial oil and gas pools are confined to all sandy suites and horizons. The upper boundary of the industrial oil-gas content here is horizon II Surakhany suite (the upper division of the PS), and the lower-the Infra-Kirmaki suite (PK) (the lower division of the PS) (see Fig. 1).

In the interval of the stratigraphic section from the top of the Kirmaki suite (KS) to the top of the Surakhany suite 17 sandy-silt oil and gas-bearing layers are distinguished, which are separated by thin clayey sections. Trap fill factor is 0.47 .

The oil deposits of the upper division of the PS (up to the Supra-Kirmaki clayey suite-NKG) usually occupy the crest of fold. Starting from the Supra-Kirmaki sandy suite (NKP), oil pools are noticeably pushed to the wings, and gas caps are located on the fold arch. The largest initial oil reserves were established in horizons II and III of the Sabunchi suite (upper division of PS), and in the lower division of PS the largest oil and gas reserves are characteristic for PK.

\section{Garadag field}

The Garadag field/UGS (underground gas storage) is located on the southern limb of the asymmetrical anticline fold of the same name, in the far southwest of the Absheron Peninsula, $30 \mathrm{~km}$ from Baku (see Fig. 1). 

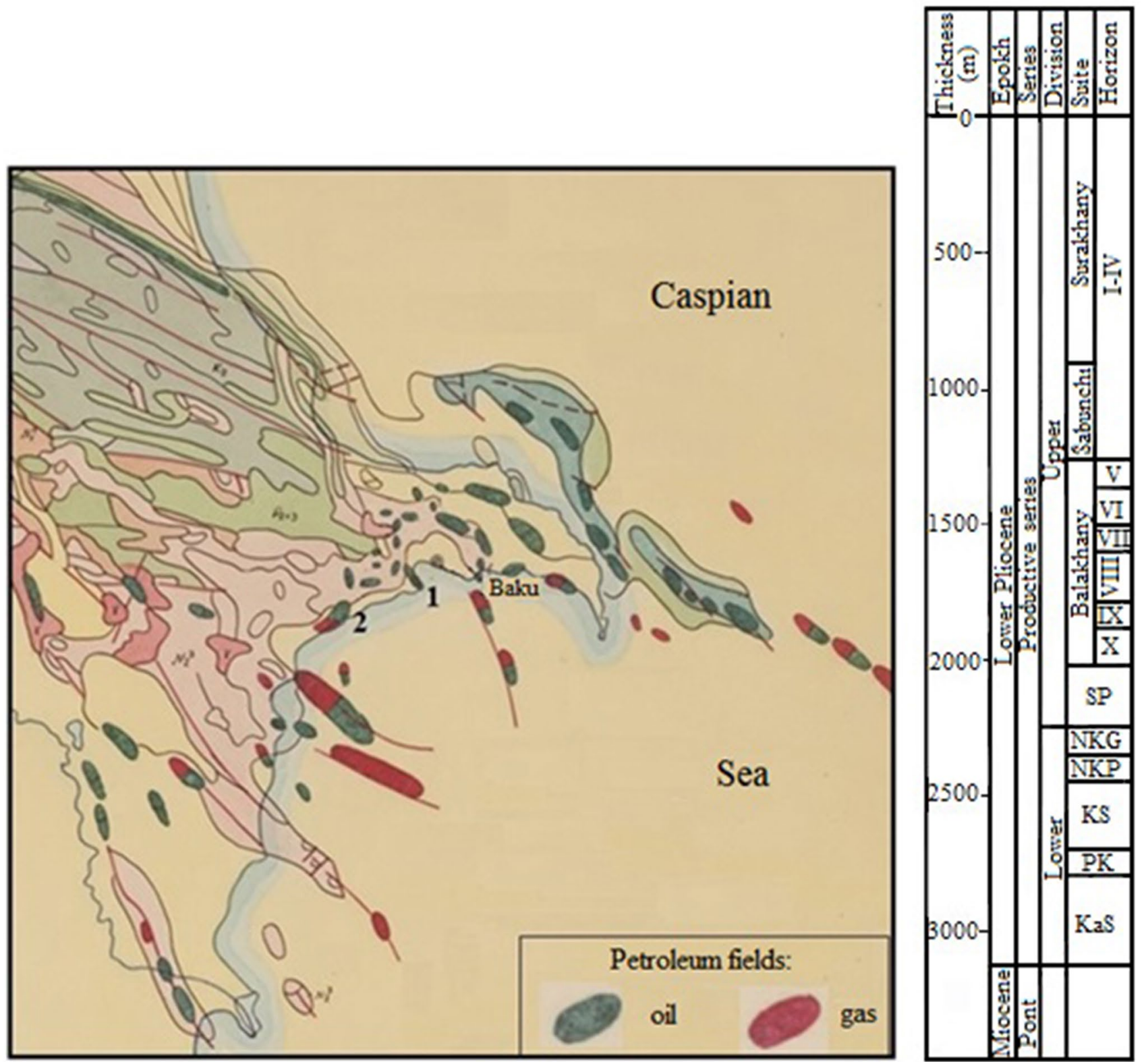

Fig. 1 Locations of the studied fields of the SCB (1-Bibieybat; 2-Garadag) and the stratigraphic section of the Productive Series: SP-«Pereryva» suite; NKG- Overkirmaki clayey suite; NKP-Overkirmaki sandy suite; KS-Kirmaki suite; PK-Underkirmaki suite; KaS-Kala suite

The Garadag brachyanticline fold has a block structure and complicated by parallel faults of the thrust type. The amplitudes of the faults are $600-500 \mathrm{~m}$ on the western pericline and decrease to $100 \mathrm{~m}$ on the eastern pericline (Fig. 3).

The gas condensate pool of horizon VII of the PS (an analog of the NKG suite of the lower division of PS in the Absheron nomenclature-see Fig. 1) is distinguished from others by high productivity (Akhmedov et al. 1964; Panakhov and Agayev 1985).
A gas condensate pool with an oil rim in the VII horizon (average depth $3125 \mathrm{~m}$ ) was put into development in 1955 and was developed without maintaining formation pressure.

For the period from 1955 to 1978 more than 20.5 billion $\mathrm{m}^{3}$ of gas were produced from the VII-VIIa horizons (Karger et al. 2013).

Horizons VII were recommended for underground gas storage (UGS). 


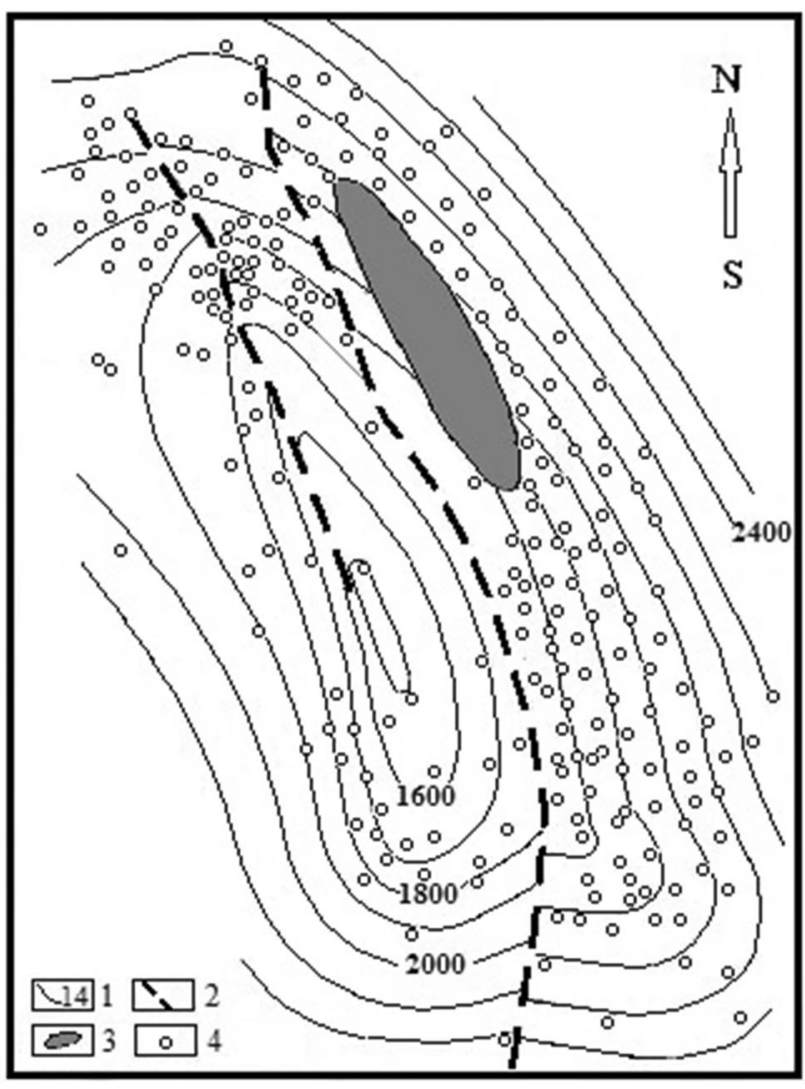

Fig. 2 Structural map of the Bibieybat deposit on the top of the PS: 1-lines of tectonic faults; 2-isolines of the top of structure; 3-buried mud volcano

\section{Results}

\section{Bibieybat field}

Figure 4 shows graphs of changes in the annual total oil production (4a) and the average production rate per well (4b) for the period from 1935 to 2018 .

As can be seen from Fig. 4, from the beginning of development (since 1935) after a short period (up to about 5 years from the beginning of development), a continuous decline in oil production was observed at the Bibieybat field, especially intense in the first 30 years. However, since about 1995, stabilization of production has been observed.

The stable average daily oil production per well established at the late stage of field development varies between 0.32 and 0.89 tons (average 0.71 tons) for productive facilities in the upper division of PS and $0.88-1.4$ tons (average 1.0 tons).in the lower division of PS.

The drop of oil production in the process of intensive development of field is accompanied by a steady drop in formation pressure, despite the artificial pressure maintenance in the reservoir by pumping water.

Initial reservoir pressures vary with depth close to hydrostatic pressure. However, during the development process, this pattern is violated, and the values of the current reservoir pressures fall significantly below the hydrostatic level,

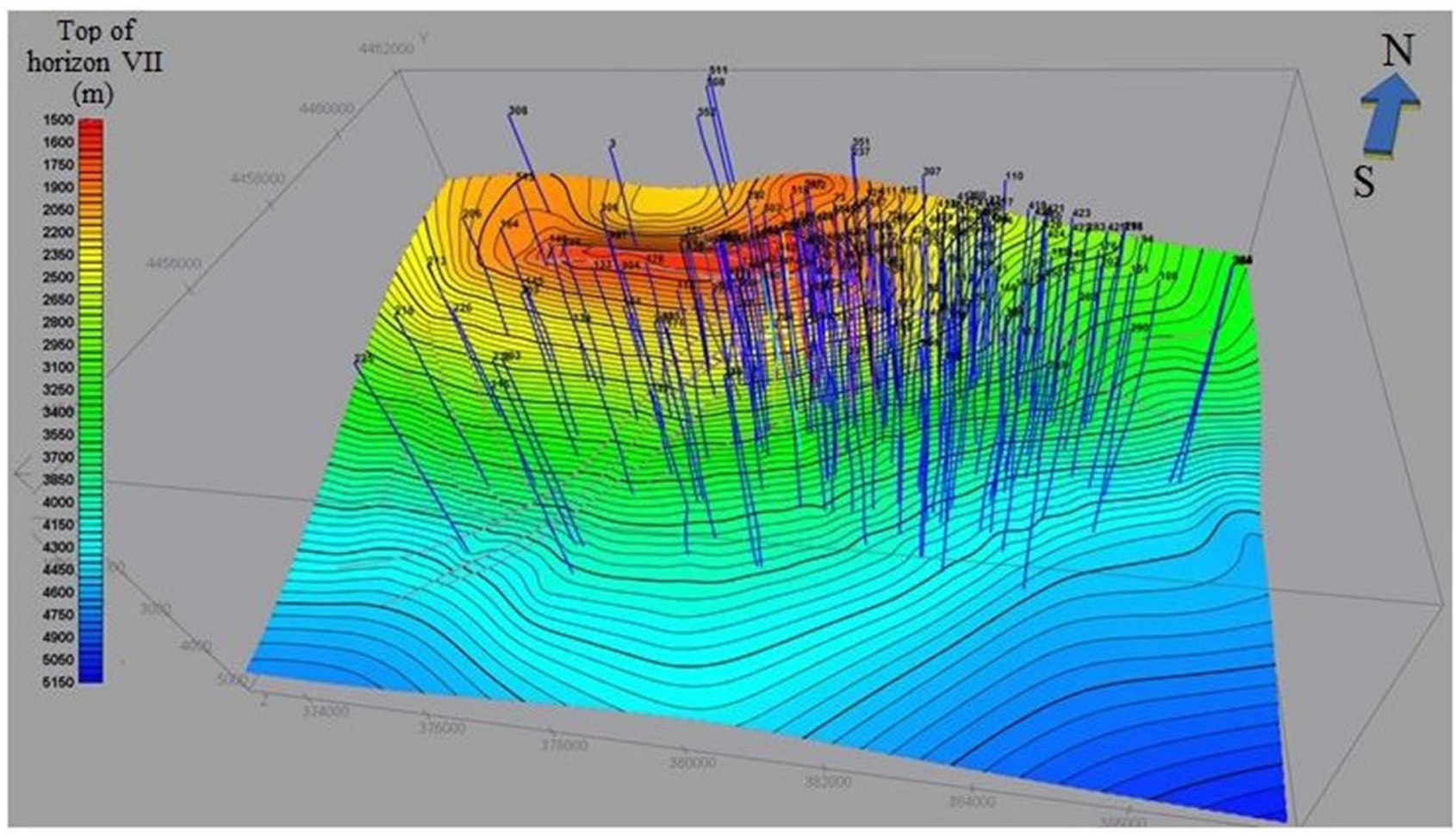

Fig. 3 Structural model of horizon VII of the Garadag field

$\checkmark$ 
Fig. 4 The Bibieybat field. Dynamics of changes in total annual oil production (a) and average oil production rate per well (b)

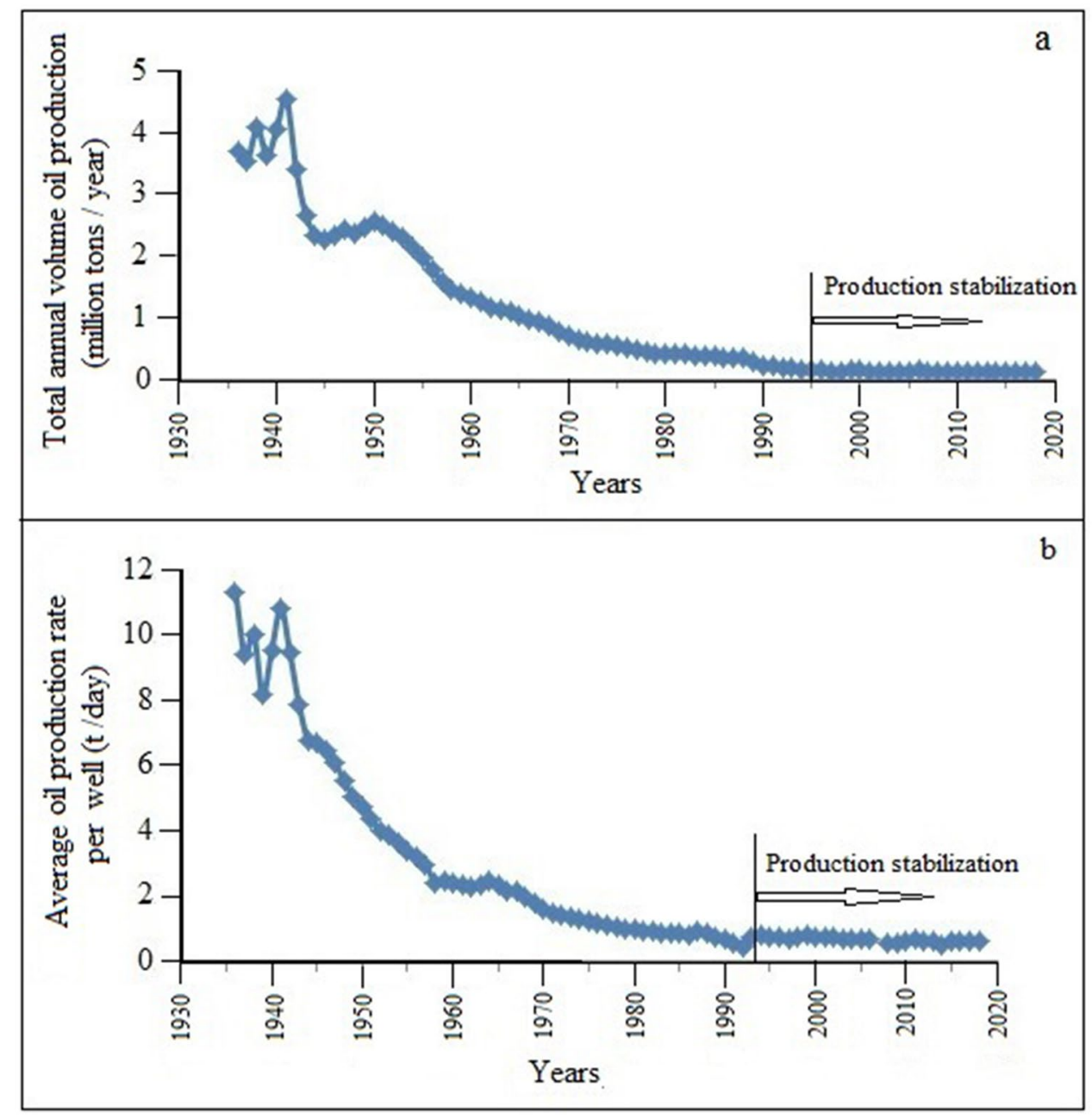

forming abnormally low formation pressures (Koshlak 2002; Huffman and Bowers 2002).

According to Moos and Chan (1998), activities to maintain formation pressure by injecting water into the reservoir and other methods used at many fields in the world can restore pressure (and as a result, a corresponding increase in productivity) by no more than $10 \%$.

Such is also confirmed by the oldest Balakhany-Sabunchu-Ramany field on the Absheron Peninsula of the SCB. Here, during the development of the VI horizon of the PS from 1935 to 2001 formation pressure dropped 10 times. Horizon productivity over the same period decreased by almost 4 times in comparison with the peak value. Injection of water in order to maintain pressure increased oil production to only $9 \%$ of the peak value, increasing water production to a greater degree.

The nature and level of pressure drop in the productive objects of the upper and lower divisions of the PS differ noticeably (Fig. 5).

\section{Garadag field}

The dynamics of gas production and the condensate contained in it at the Garadag field for the period from the beginning of development (1955) to its completion (1979) is shown in Fig. 6.

From Fig. 6, the peak in gas production, due to its intensive extraction, was reached about 2-3 years after the start of field development, and then followed a steady decline in production. The average daily production per well stabilized approximately 5-6 years before the completion of the development of the pool.

Field development in the depletion mode (without maintaining formation pressure) contributed to a high rate of reservoir pressure drop (Table 1).

The initial formation pressure equal to $39.7 \mathrm{MPa}$, by the end of field development, has decreased by more than 10 times, amounting to $3.6 \mathrm{MPa}$. A particularly intense rate of pressure drop was observed in the first 5-6 years of field development (Fig. 7). 


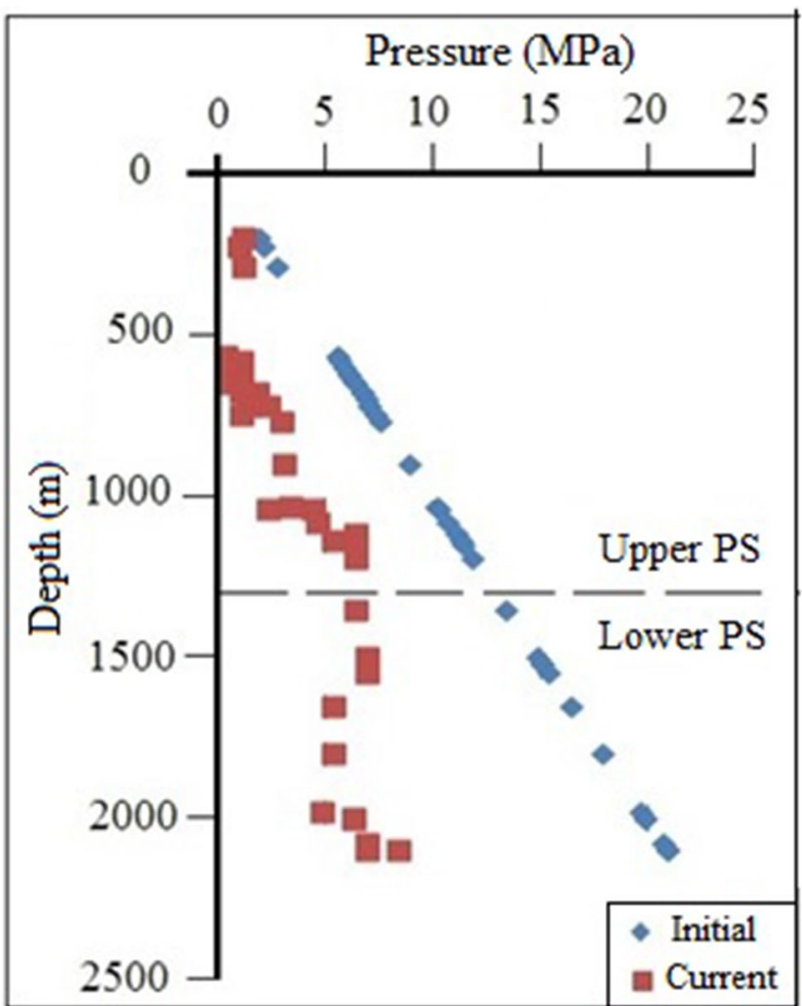

Fig. 5 Initial and current values of formation pressures vs. depth at Bibieybat field

\section{Discussion}

The formation of an industrial accumulation of HCs in the subsurface occurs over a long geological time. Even for the relatively young fields in the Lower Pliocene sediments of the SCB, formation took about 2-3 million years. This process is completed with the establishment of a natural dynamic equilibrium in the rock-fluid system.

Human activities associated with the development of oil and gas fields and intensive extraction of fluids (oil, gas, water) from the reservoir for a very short (compared to geological time) period of time, accompanied by a continuous drop in reservoir pressure, leads to a sharp violation of this equilibrium contributing to the development of irreversible deformation processes in the reservoir and to a decrease in the reservoir quality.

Thus, the results of experimental studies of two sandstone samples under conditions as close as possible to the real reservoir conditions showed that a decrease in reservoir pressure from 110 to $10 \mathrm{MPa}$ was accompanied by a decrease in their permeability, by 15 and 50\%, respectively, under constant all-round pressure (Kharroubi et al., 2004).
The experiments carried out by Chan (2004) using rock samples from fields in the Gulf of Mexico also led him to conclude that inelastic deformation associated with HC production could lead to irreversible loss of porosity and permeability. Moreover, a relative decrease in rock permeability is more significant in comparison with a decrease in porosity: A decrease in rock porosity by $10 \%$ is often accompanied by a decrease in permeability by about $70 \%$ from the initial value.

The results of other studies led to the same conclusion. For example, according to estimates by Chan and Zoback (2007), a decrease in the porosity of rocks from 23 to $21 \%$ is accompanied by a decrease in permeability from $230 \mathrm{mD}$ to $50-140 \mathrm{mD}$. According to other experimental studies (Liu et al 2004), with a decrease in formation pressure and, consequently, an increase in effective pressure by $20 \mathrm{MPa}$, a relative decrease in porosity and permeability occurs, respectively, by 13 and $80 \%$ for fractured rocks and by $2 \%$ and $60 \%$ for granular rocks.

A decrease in the reservoir properties of rocks associated with a decrease in reservoir pressure occurs most intensively at the initial stage of development of HC pools (Liu et al. 2004; Feyzullayev et al. 2012).

At the late stage of field development, a new technogenicnatural equilibrium occurs in the reservoir, due to the fact that the steady low volume of the extracted HC fluid comes into line with the rate of natural recharge. The extracted volume of HCs is compensated by the volume of natural replenishment of the reservoir. Based on the analysis of production dynamics at the Bibieybat field, the estimated rate of natural well replenishment with oil at various production facilities varies over a wide range: 0.32-1.4 t/day (Fig. 8).

The modal value of the steady low, but stable, oil production from 29 production facilities in the section of PS at the Bibieybat oil field, which is supposedly equivalent to the rate of natural inflow into the oil reservoir, is in the range of $0.7-0.9 \mathrm{t} /$ day, averaging $0.76 \mathrm{t} /$ day.

The rate of natural daily recharge of wells at the Garadag field as a whole is estimated at about 5.2 thousand $\mathrm{m}^{3}$ of gas and 0.9 tons of condensate.

The wide range of times and levels of onset of stable oil and gas production are determined by the influence of complex factors. Such factors are most likely to be reservoir pressure and temperature, as well as rock permeability, which correlates well with oil and gas production (Figs. 9, 10 and 11).

No relationship is observed between oil production and reservoir parameters such as its effective (oil-saturated) thickness and porosity of rocks for the Bibieybat field.

The direct relationship between the volume of oil production and reservoir temperature, according to (Barker 1972), may be associated with a decrease in oil density as a result of an increase in reservoir temperature. 
Fig. 6 Garadag field. Dynamics of the average daily production of gas (a) and condensate (b) per well

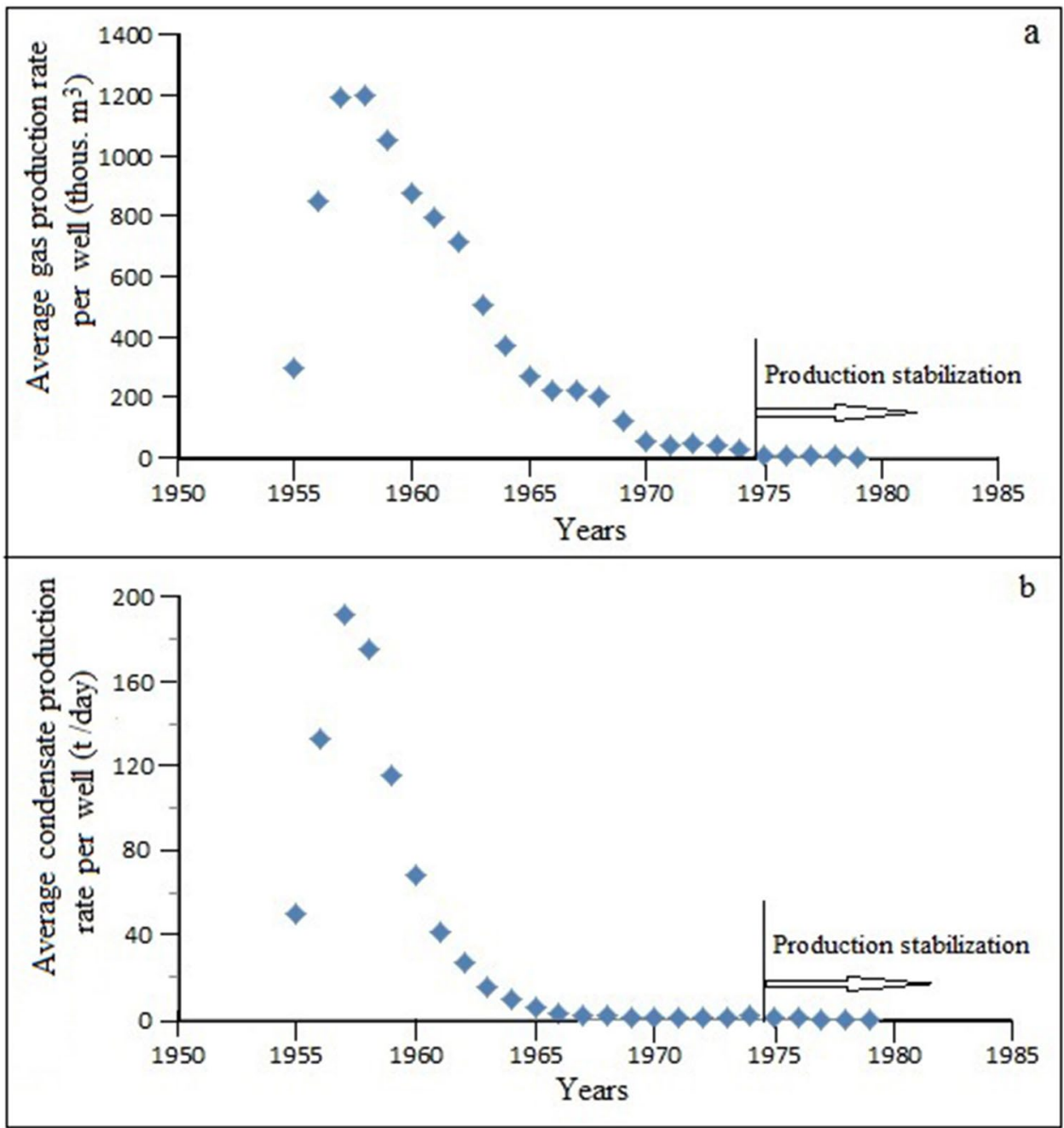

Table 1 Rate of pressure drop in wells of the Garadag field

\begin{tabular}{llll}
\hline Well & $\begin{array}{l}\text { Time interval between } \\
\text { measurements (month) }\end{array}$ & $\begin{array}{l}\text { Total pres- } \\
\text { sure drop } \\
(\mathrm{MPa})\end{array}$ & $\begin{array}{l}\text { Monthly average } \\
\text { pressure drop } \\
(\mathrm{MPa})\end{array}$ \\
\hline 70 & 15.0 & 7.4 & 0.49 \\
134 & 14.8 & 6.5 & 0.44 \\
132 & 15.7 & 5.2 & 0.33 \\
182 & 15.7 & 5.2 & 0.30 \\
Average & 0.39 & & \\
\hline
\end{tabular}

Other things being equal (permeability and temperature), a sharp drop in formation pressure in the reservoir during its development enhances the inflow of HCs from the outside. Naturally, there must be HC supply channels, the role of which can be played by tectonic faults (Trofimov 2013) and under the conditions of the SCB, also channels of mud volcanoes.
With the dominant epigenetic concept of the formation of HC fields in the SCB (Wavrek et al. 1996; Inan et al. 1998; Katz et al. 2000; Feyzullayev et al. 2001; Gurgey 2003) and their young age (formation does not exceed 2 million years) most $\mathrm{HC}$ mass transfer from the source to the reservoir likely occurred due to filtration (subvertical migration along deep faults, channels of mud volcanoes) (Feyzullayev 2011).

Most likely, these channels serve as pathways of the enhanced (recovered) HC migration into the reservoir as a result of long-term exploitation of field. The presence of such zones of localization of highly productive wells is also seen in the example of oil fields: Guneshli and Galmas in the SCB (Feyzullayev 2013; Feyzullayev et al. 2017).

At present, methodological approaches to identifying $\mathrm{HC}$ inflow zones have been developed (Muslimov et al. 2004), based on the identification of highly productive (abnormal) wells, as well as a complex of geochemical studies of dissolved oils and gases. 


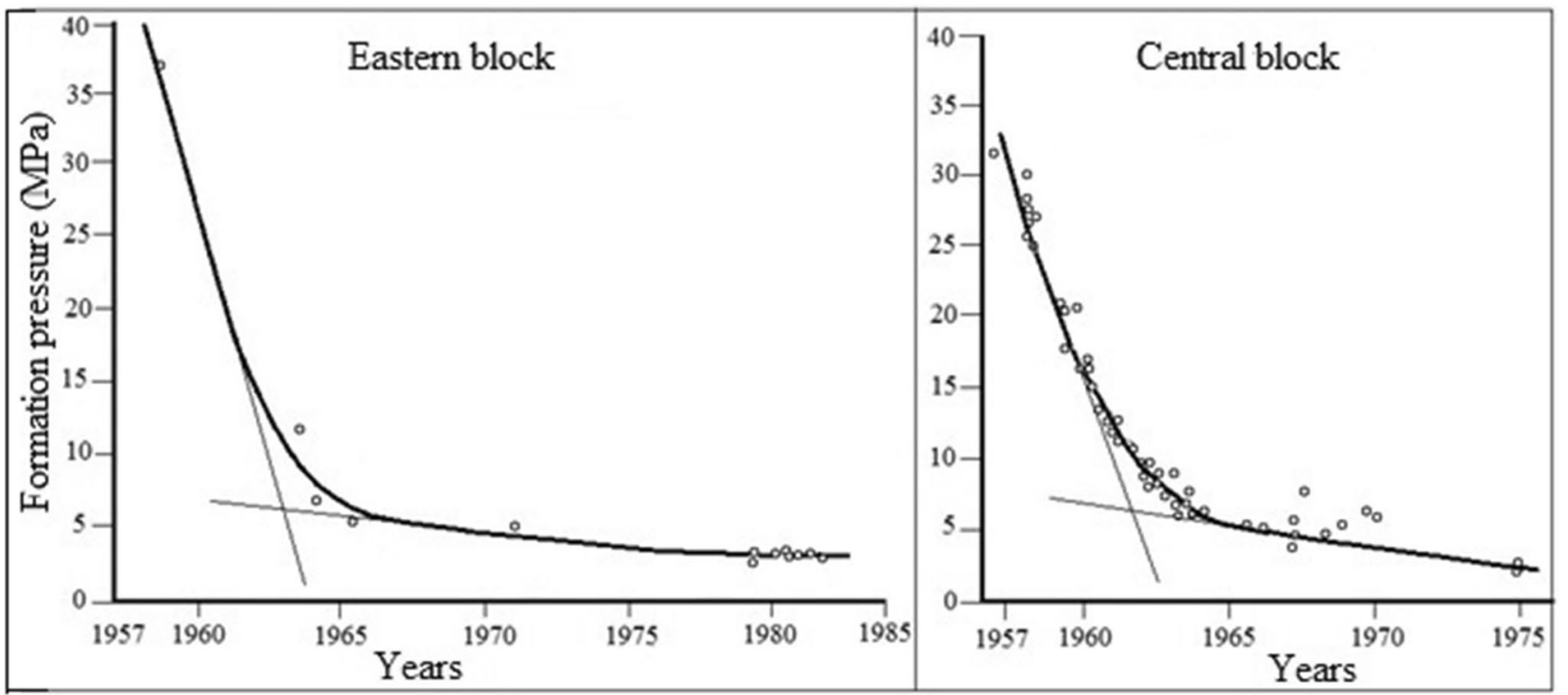

Fig. 7 Change in reservoir pressure during the development of the Garadag field

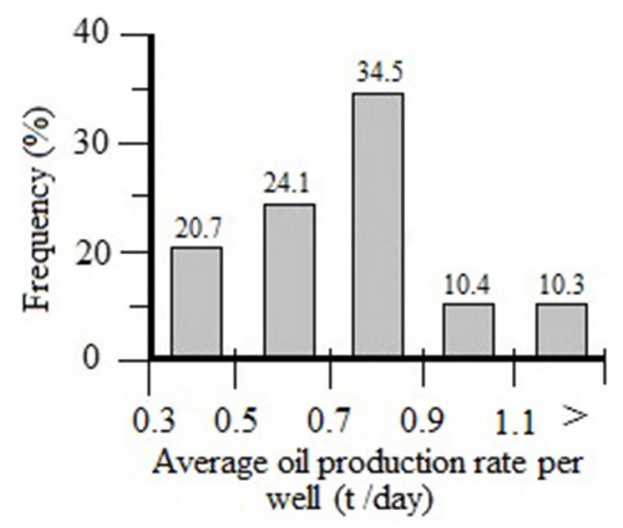

Fig. 8 Histogram of the distribution of steady-state daily average oil production per well for various productive facilities at a late stage in the development of the Bibieybat field
The above data indicate that the migration of HC fluids in the sedimentary section occurs at a much higher rate than previously assumed and continuously ongoing to date.

A real-time example of modern fluid dynamics in SCB is natural gas manifestations and mud volcanoes that continuously emit gas (mainly methane), and some periodically discharge large volumes of gas into the atmosphere during their eruptions (Fig. 12).

The intensity of natural gas manifestation and the frequency of eruptions of each individual mud volcano are determined by the rate of replenishment of the deep source (reservoir) with gas. During the eruption of a mud volcano, as well as in the fields, the flow of HCs is enhanced by a sharp drop in pressure in the deep source caused by the natural discharge into the atmosphere (and at the field by intensive technogenic extraction) of large volumes of gas.

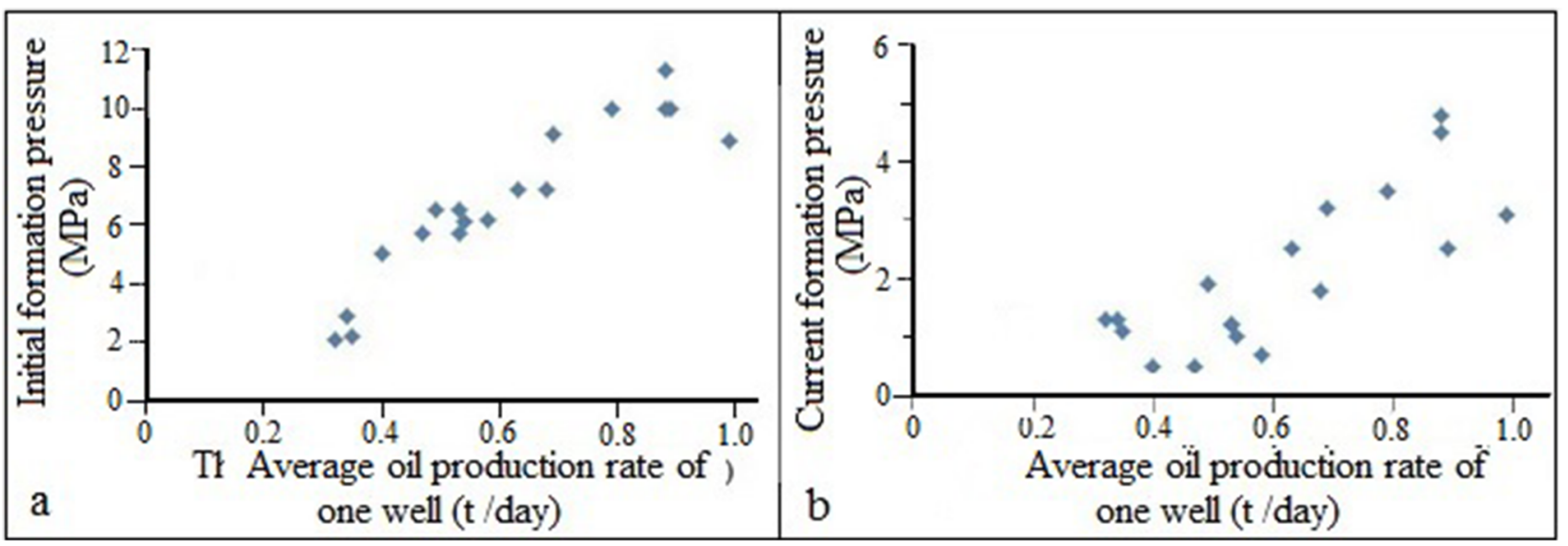

Fig.9 The Bibieybat field showing the average daily oil production per well versus initial (a) and current (b) formation pressures 


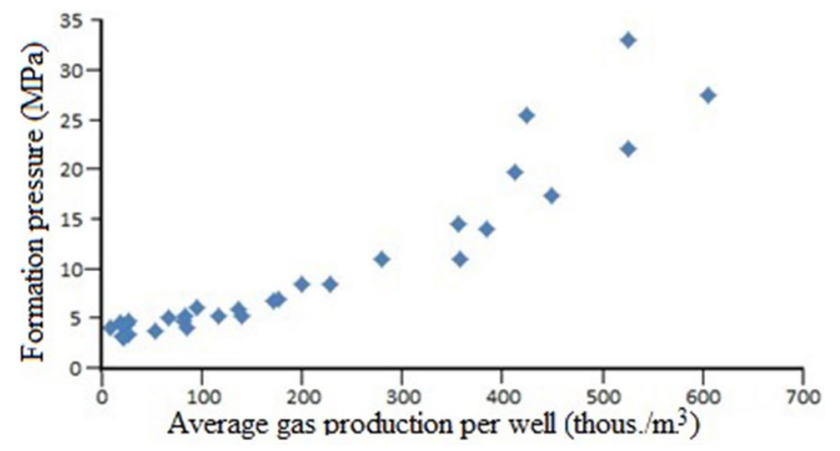

Fig. 10 Garadag field. Average daily gas production per well vs. formation pressure

The proposed methodological approach and the probabilistic estimates of the volumetric rate of natural replenishment of the developed fields with oil and gas can be considered objective for the geological conditions of the $\mathrm{SCB}$, characterized by favorable conditions for focused fluid flows.

\section{Conclusion}

An analysis of the dynamics of oil and gas production in combination with other field data, performed on the longdeveloped Bibieybat oil and Garadag gas-condensate fields in SCB, allows us to conclude that forced extraction of fluids (oil, gas and water) during field operation, accompanied by a sharp drop in reservoir pressure (significantly lower than hydrostatic), violates the established natural balance in the reservoir and so causes a natural inflow of $\mathrm{HC}$ fluids.

Volume of HC fluids at a late stage of development begins to compensate for the amount extracted leading to the emergence of a new natural-technogenic equilibrium in the reservoir. Based on this phenomenon, estimates of the

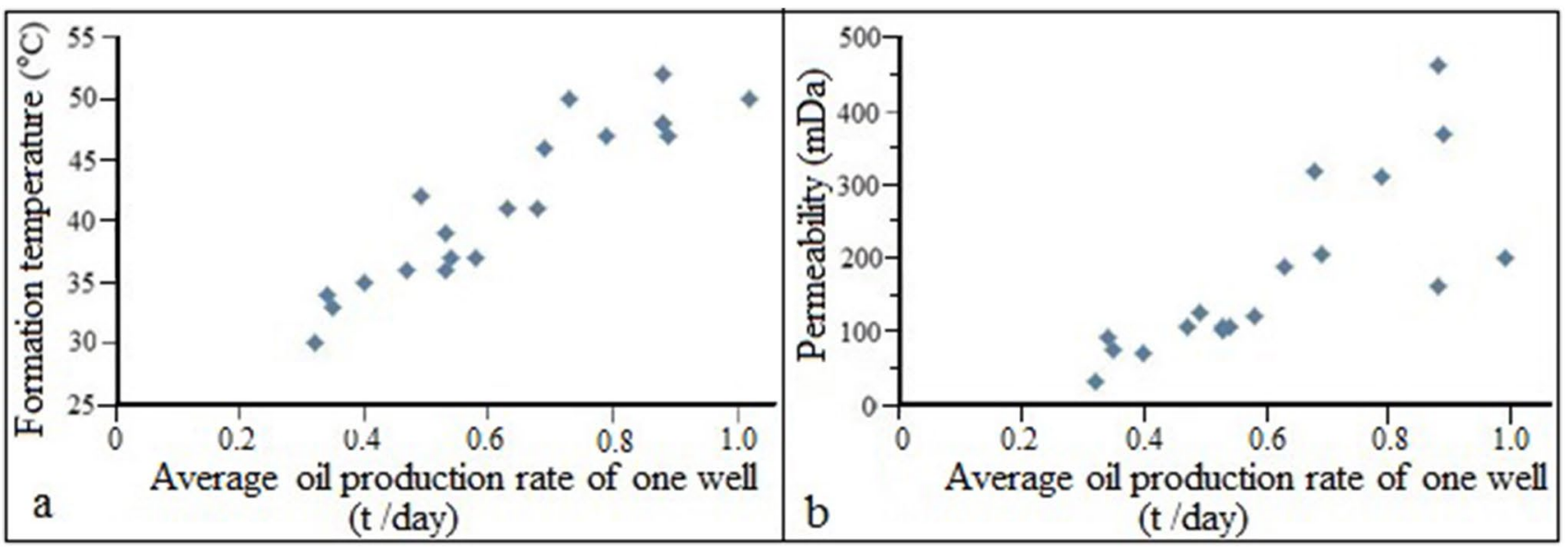

Fig. 11 The Bibieybat field. The average daily oil production per well vs..formation temperature (a) and rock permeability (b) of productive objects

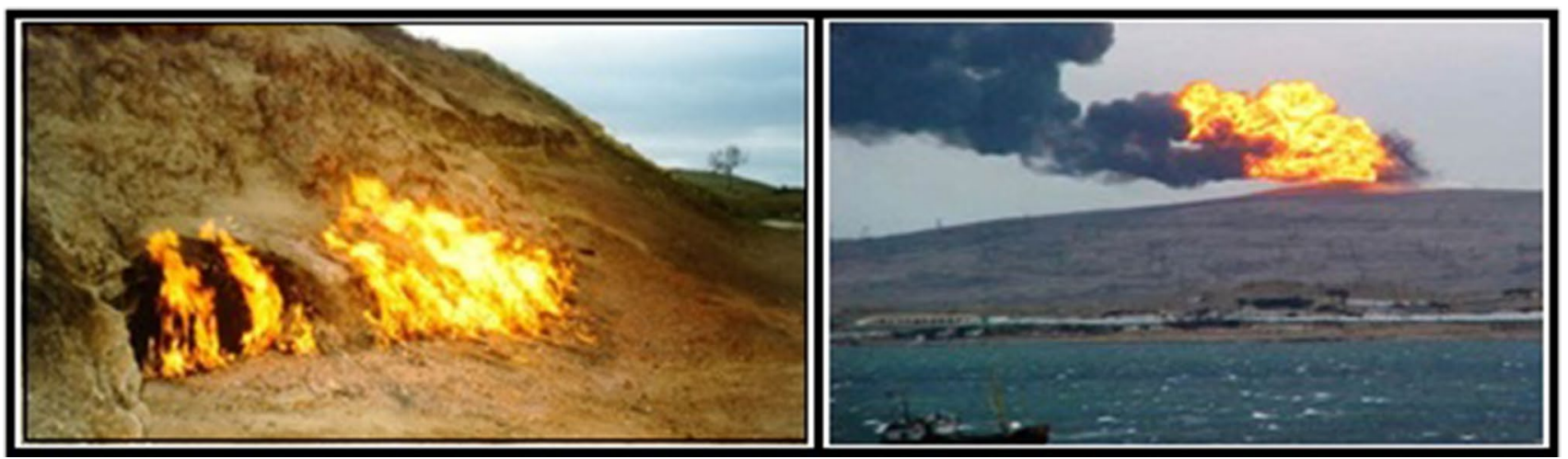

Fig. 12 SCB. Absheron Peninsula. "Yanardag" burning natural gas discharge (at the left) and eruption of the Lokbatan mud volcano 
rate of natural inflow of oil are on average $0.76 \mathrm{t} /$ day and gas-about 5.2 thousand $\mathrm{m}^{3} /$ day.

On the example of the considered fields, the stabilization of oil and gas production begins approximately about 60 years after their development. Therefore, the proposed method for assessing the rate of natural inflow can be applied only for long-term developed fields.

In summary oil and gas fields can be exploited more efficiently and for a very long time if $\mathrm{HC}$ production is carried out on the basis of a balance of extracted and recharged volumes.

\section{Compliance with ethical standards}

Conflict of interest The authors declare that they have no known competing financial interests or personal relationships that could have appeared to influence the work reported in this paper.

Funding The authors received no financial support for research, authorship, and/or publication of our article.

Open Access This article is licensed under a Creative Commons Attribution 4.0 International License, which permits use, sharing, adaptation, distribution and reproduction in any medium or format, as long as you give appropriate credit to the original author(s) and the source, provide a link to the Creative Commons licence, and indicate if changes were made. The images or other third party material in this article are included in the article's Creative Commons licence, unless indicated otherwise in a credit line to the material. If material is not included in the article's Creative Commons licence and your intended use is not permitted by statutory regulation or exceeds the permitted use, you will need to obtain permission directly from the copyright holder. To view a copy of this licence, visit http://creativecommons.org/licenses/by/4.0/.

\section{References}

Akhmedov GA, Chernomordinov MZ, Agalarov MS, Movsum-zade SA, Sadykh-zade ES (1964) Calculation of underground oil and gas reserves in the Garadag field as of 1.1.1962. AzNII DN. Baku (in Russian)

Ashirov KB, Borgest TM, Karev AL (2000) Justification of the reasons for the multiple replenishment of oil and gas reserves in the developed fields of the Samara region. Bull Samara Sci Center Russian Acad Sci 2(1):166-173 ((in Russian))

Barker C (1972) Aquathermal pressuring-role of temperature in development of abnormal-pressure zones. AAPG Bull 56:2068-2071

Campbell CJ (2002) The assessment and importance of oil depletion. Abstract for International workshop on oil depletion. Uppsala, Sweden, May 23-25, 2002

Chan AW (2004) Production-induced reservoir compaction, permeability loss and land surface subsidence. PhD thesis. Stanford University

Chan AW, Zoback MD (2007) The role of hydrocarbon production on land subsidence and fault reactivation in the Louisiana Coastal Zone. J Coastal Res 23(3):771-786

Feyzullayev AA (2013) Migration pathways of hydrocarbons in SouthCaspian basin. Geol Geosci 2(3):1-6
Feyzullayev AA, Guliyev IS, Tagiyev MF (2001) Source potential of the Mesozoic-Cenozoic rocks in the South Caspian Basin and their role in forming the oil accumulations in the lower Pliocene reservoirs. Pet Geosci 7(4):409-417

Feyzullayev AA, Velieva EB, Gasanov AZ (2012) Features of changes in reservoir pressure in the long-developed fields of the Absheron Peninsula (case study: the Gala field). Trans ANAS, Earth Sci 4:3-12 ((in Russian))

Feyzullayev, A.A.., Gojayev, A.G., Ismaylova, G.G., Mirzoeva, D.R., 2017. Analysis of the influence of lithofacial heterogeneity of the reservoir on the operation mode of the underground gas storage Galmas (Azerbaijan). Oil and gas geology. Theory and practice 13(2), 1-12

Gavrilov VP (2008) Possible mechanisms for the natural replenishment of reserves in oil and gas fields. Geologiya nefti i gaza 1:56-54 ((in Russian))

Goloskokov AN (2010) The peak of oil production and the beginning of the global energy crisis. Neftegazovoe delo 2:1-13 ((in Russian))

Goryunov EYu, Ignatov PA, Klementyeva DN, Khalikov AN, Kravchenko MN (2015) Manifestations of modern hydrocarbon inflows to oil and gas complexes in the Volga-Ural oil and gas province. Geologiya nefti i gaza 5:62-69 ((in Russian))

Gurgey K (2003) Correlation, alteration, and origin of hydrocarbons in the GCA, Bahar, and Gum Adasi fields, western South Caspian Basin: geochemical and multivariate statistical assessments. Mar Pet Geol 20(10):1119-1139

Hubbert MK (1956) Nuclear Energy and the Fossil Fuels. Presented before the Spring Meeting of the Southern District, American Petroleum Institute, Plaza Hotel, San Antonio, Texas, March 7-9.

Huffman, A.R., Bowers, G.L., 2002. Pressure Regimes in Sedimentary Basins and Their Prediction: An Outgrowth of the International Forum Sponsored by the Houston Chapter of the American Association of Drilling Engineers. Houston, TX, September 2-4, 2002

Iktisanov BA, Zakirov SN (2019) Features of the stage of stable production of long-developed oil fields. Oil province 3(19):44-60 ((in Russian))

Inan S, Yalcin NM, Guliev SI, Kuliev KG, Feyzullayev AA (1998) Deep petroleum occurences in the Lower Kura depression, South Caspian Basin, Azerbaijan. An organic geochemical and basin modelling study. Mar Pet Geol 14:731-762

Karger MD, Fidens SA, Berman LB, Neiman VS, Trofimov DM, Zakharov AI, Volpin SG (2013) Construction of a block filtration model of the Garadag underground gas storage and recommendations for a gas injection and extraction system. Final report on the Project, Baku (in Russian)

Kasyanova NA (2010) Geofluidodynamic evidence of modern replenishment of oil and gas reserves. Geology, geography and global energy 3(38):14-16 ((in Russian))

Katz KJ, Richards D, Long D, Lawrence W (2000) A new look at the components of the petroleum system of the South Caspian Basin. J Petrol Sci Eng 28:161-182

Kayukova GP, Romanov GV, Plotnikova IN (2012) Geochemical aspects of the study of the process of replenishment of oil deposits. Georesources 47(5):37-40 ((in Russian))

Kharroubi A, Layan B, Cordelier P (2004) Influence of pore pressure decline on the permeability of North Sea sandstones. International Symposium of the Society of Core Analysts, Abu Dhabi

Khisamov RS, Ibatulin RR, Amerkhanov MI, Slesareva SS (2012) Evaluation of a possible inflow of deep hydrocarbons into the developed pools of the Romashkinskoye field (case study: Minnibaevsk area). Georesources 5(47):48-51 ((in Russian))

Kontorovich AE (2009) The peak of world oil production will be in 2030-40. "Oil of Russia", December 25, 2009, Moscow (in Russian). http://www.oilru.com/news/155041/ 
Koshlak VA (2002) Granitoid oil and gas reservoirs. Tau Publishing House, Ufa

Kucherov VG (2016) Renewable oil: myth or reality? Newspaper NGEnergy 09(02):2016 ((in Russian))

Liu J-J, Feng X-T, Jing LR (2004) Theoretical and experimental studies on the fluid-solid coupling processes for oil recovery from low permeability fractured reservoirs. Int J Rock Mech Min Sci 41(3):1-6. https://doi.org/10.1016/j.ijrmms.2003.12.032

Moos D, Chang C, (1998) Relationships between porosity, pressure, and velocities in unconsolidated sands. Paper presented at Overpressures in Petroleum Exploration" workshop, Pau, France, April 1998

Muslimov RKh (2007) A new look at the development prospects of the super-giant Romashkinskoye field. Geologiya nefti I gaza 1:3-12 ((in Russian))

Muslimov RK, Plotnikova IN (2018) Taking into account the processes of reformation of oil deposits during long-term operation and deep recharge in modeling oil field development. Georesources 20(3):186-192

Muslimov RKh, Glumov IF, Plotnikova IN, Trofimov VA, Nurgaliyev DK (2004) Oil and gas fields are self-developing and constantly renewable facilities. Geol Oil Gas 9:43-49

Oil shortage will become noticeable by 2020 . Vedomosti. October 08, 2009 (in Russian). https://www.vedomosti.ru/library/ news/2009/10/08/issledovanie-deficit-nefti-stanet-oschutimym $-\mathrm{k}-2020-\mathrm{g}$

Panakhov RA, Agayev FT (1985) Technological scheme of pilot operation of the second. stage of the Garadag underground gas storage. Report of VNIPIGaz. Baku (in Russian)

Peak of oil., 2010. Material from Wikipedia - the free encyclopedia (in Russian). https://ru.wikipedia.org/wiki/Pik_nefti
Plotnikova IN (2004) Geological, geophysical and geochemical prerequisites for the prospects of oil and gas potential of the crystalline basement of Tatarstan. Nedra, Saint-Petersburg (in Russian)

Sokolov BA, Guseva AN (1993) About the possibility of fast modern generation of oil and gas. Bulletin of Moscow State University, Ser. 4. Geology 3:39-46 ((in Russian))

Trofimov VA (2013) A radical solution to the issue of increasing oil recovery of the "old" fields is oil production directly from oil supply channels. Georesources 4(54):65-68 ((in Russian))

Wavrek D, Collister J, Curtiss D, Quick J, Guliyev I, Feyzullayev A (1996) Novel Application of Geochemical Inversion to Derive Generation/Expulsion Kinetic Parameters for the South Caspian Petroleum System (Azerbaijan). AAPG/ASPG Research Symposium. "Oil and Gas Petroleum Systems in rapidly subsiding basins", October 6-9, Baku, Azerbaijan

Zakirov SN, Kondrat RM, Volosnik EA, Barenbaum, AA, Zakirov ES, Lukmanov AR (2009) Renewable oil and gas reserves. Forecast and facts. Proceed. of II International Scientific Symposium "Theory and practice of applying methods of enhanced oil recovery”. VNIIneft, Moscow. September 15-16, 2009, Volume II, pp. $157-161$

Zapivalov NP (2012) The dynamics of the life of an oil field. News Tomsk Polytech Univ 321(1):206-211 ((in Russian))

Publisher's Note Springer Nature remains neutral with regard to jurisdictional claims in published maps and institutional affiliations. 